\title{
o papel do Corpo Editorial
}

Ser convidado para fazer parte do Corpo Editorial de uma revista é uma honra para qualquer profissional, uma vez que tal convite é um reconhecimento à sua capacidade técnica e científica, qualificando-o para avaliar criticamente os trabalhos enviados para a revista, sendo o seu parecer o maior parâmetro para a seleção do que deve ser publicado.

Ter o nome no Corpo Editorial de revistas sérias e conceituadas, como o são as duas revistas nacionais de Radiologia, engrandece o currículo de qualquer radiologista. Tal honra, em contrapartida, gera compromissos sérios dos membros do Corpo Editorial com a comunidade radiológica, o principal deles sendo exercer a função, quando solicitado, com equilíbrio, eficiência e presteza.

É até compreensível que alguns profissionais, por absoluta falta de tempo, não possam desempenhar esta tarefa. A conduta mais correta, nestes casos, é declinar o convite, ou, quando a dificuldade for temporária, pedir um prazo de liberação.

É, contudo, uma absoluta falta de respeito com os autores a negligência com que por vezes esta tarefa é encarada, ficando os artigos meses a fio com os revisores, algumas vezes sendo extraviados ou perdidos.

Quando se imagina as dificuldades de um autor, por vezes fora dos grandes centros, em levantar a literatura sobre o assunto, documentar os seus casos, fazer as fotografias, conseguir tempo para redigir o texto, não se concebe que este trabalho seja desrespeitado, colocado em segundo plano em uma gaveta, quando não, perdido. Isto deixa também as secretárias das revistas em situação difícil, uma vez que foge do alcance delas a cobrança, criando um constrangimento grande quando os autores, cobertos de razão, reclamam do atraso, por vezes de anos, na avaliação de seus artigos.

É importante, neste momento que as revistas buscam um novo salto de qualidade, candidatando-se a participar de bancos de indexação internacionais, com benefícios óbvios para toda a comunidade, que cada membro dos Corpos Editoriais reavalie a sua atuação e conscientemente decida se pode e quer continuar a exercer, com seriedade e eficiência que se espera, esta honrosa tarefa.

Edson Marchiori 